\title{
WHAT IS THE IMPACT OF PERSONAL CARE PRODUCTS SELECTION ON GREYWATER
}

\section{CHARACTERISTICS AND REUSE?}

Wilfred. W. Kadewa ${ }^{a}$; Geraldine Knops ${ }^{b}$; Marc Pidou ${ }^{b}$; Paul Jeffrey ${ }^{b}$; Bruce Jefferson ${ }^{b}$,

\author{
Kristell S. Le Corre ${ }^{b *}$
}

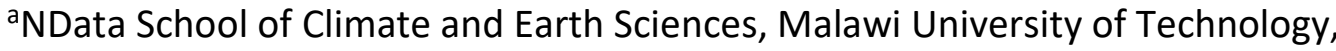
Southern Region, MALAWI.

${ }^{b}$ Cranfield Water Science Institute, Cranfield University, College Road, MK43 OAL, UK. Email : k.s.lecorrepidou@cranfield.ac.uk

\section{Highlights}

- The effects of 55 personal care and household products on greywater were studied.

- The toxicity of the products was also tested using Microtox ${ }^{\circledR}$ and MicroResp ${ }^{\mathrm{TM}}$.

- Product selection impacts both pollution load and character of greywater.

- No link could be found between the products properties and branding or price.

- Regardless of type and selection, the toxicities of the products appeared limited. 


\section{Abstract}

Accounting for up to three quarters of the wastewater volume resulting from domestic activities but containing only a third of its organic content, greywater is seen as an alternative water source for non-potable reuse. This unique study explores the question whether consumers' product selection could affect the treatability and reuse of bathroom greywater. Fifty five personal care and household products (PCHP) were analysed for their effects on a range of water quality parameters including their aquatic and soil toxicity using Microtox $^{\circledR}$ and MicroResp ${ }^{\mathrm{TM}}$. The organic content of these PCHPs varied considerably, not only from one category to another ( $0.2 \mathrm{~g}$ тос. $\mathrm{L}^{-1}$ for hair conditioners to $2.7 \mathrm{~g}$ тос. $\mathrm{L}^{-1}$ for toothpastes), but also within each category ( $0.1 \mathrm{~g}_{\text {тос. }} \mathrm{L}^{-1}$ to $3.6 \mathrm{~g}_{\text {Tос. }} \mathrm{L}^{-1}$ amongst the shampoos). As expected, the PCHPs' macronutrient content was low, suggesting some limitation towards biological treatment of bathroom greywater. Regarding the impact of product selection on toxicity towards aquatic and soil microorganisms, the results revealed a higher sensitivity of Vibrio fischeri to the individual PCHPs than the MicroResp ${ }^{\mathrm{TM}}$ soil microorganisms. In the latter case, $75 \%$ of the products caused a stimulation response from the microorganisms although some decreases in basal respiration were observed for specific PCHPs within product categories. However, based solely on MicroResp ${ }^{\mathrm{TM}}$, the short-term discharge of treated bathroom greywater, regardless of consumer product selection, is unlikely to have a negative impact on soil microbial activity. Overall, the work has demonstrated the importance of consumer choice on the pollution load and treatability of greywater. However, no clear link between greywater characteristics and factors that normally determine consumer product selection (branding, type) were identified. This means it is not currently possible for consumers to actively manage the issue through choice such that process designers and technology developers must ensure technologies are sufficiently robust to manage the potential variations that could occur.

\section{Keywords:}

Greywater, Recycling, Personal care products, Consumers choice, Physico-chemical characterisation, Microbiological soil and aquatic toxicity 


\section{Introduction}

Greywater (GW) recycling and reuse has been reported as an option to reduce the pressure on water resources and wastewater treatment facilities which results from climate change and other global pressures such as population growth, urbanisation and industrialisation. Defined as domestic wastewater originating from the bathroom (e.g. showers, hand basins, baths) and kitchen (i.e. sinks, dishwashers) appliances, but excluding toilets wastewater (Asano et al., 2007), GW can constitute from $58 \%$ to $85 \%$ of the wastewater volume generated around a house (Noutsopoulos et al., 2018). Exclusion of black water limits the pollution load associated with GW (c30\% of the organic load in sewage, Pidou et al., 2007) such that decentralised GW treatment has long been considered a simple way of recycling water for non-potable reuse purposes including toilet flushing, garden irrigation or any other outdoor activities (e.g. car washing), hence reducing households' freshwater demand (Eriksson et al. 2002). Segregating kitchen and laundry GW from bathroom $\mathrm{GW}$, also referred to as light GW, can further reduce the contaminant load in GW, while still covering up to 50\% domestic water volumes (Oktor, K. and Çelik, D., 2019).

Despite obvious benefits including reductions in freshwater needs, domestic water supply costs and wastewater volumes requiring treatment, the treatment of GW can be complex due to the high variability of its physico-chemical and microbiological properties resulting from households' activities (SI - Tables S1, S2a\&b). This variability is the result of a combination of factors including water supply quality, water usage and most importantly the type, frequency and quantity of products (personal care and household products PCHPs) used during various household activities (Oteng-Peprah et al., 2018). The products contain surfactants, fragrances, preservatives, UV filters, solvents, antiseptics and flavours, commonly categorised as "xenobiotic organic compounds (XOCs)" which can further impact overall characteristics, reduce treatability or impact end uses such as irrigation (Hernández-Leal et al., 2010). Previous investigations have identified 900 substances, mainly from PCHPs that could be present in GW (Eriksson et al, 2002). However, the specific chemicals in PCHPs are likely to regularly change as their formulations are constantly evolving due to product reformulations that typically occur at an annual rate of $25 \%$ to $30 \%$ including $10 \%$ which are new to the sector (Cosmetics Europe, 2017). Ultimately, this raises a question as to the impact of consumer choice on 
the nature and treatability of GW and hence what role can consumers play in managing the successful reuse of GW. This is expected to include changes in the overall pollutant load, its characteristics and potential toxicity to both aquatic and soil based microbial communities. The potential negative impact is poorly treated GW, reducing the aesthetic quality and impairing the associated disinfection processes through exerting additional disinfectant demand (Winward et al, 2008a) or shielding potential pathogens (Winward et al., 2008b).

To date, work that would inform on this question has been almost exclusively focussed on the potential impact of individual chemicals such as triclosan (Dhillon et al., 2015), fragrances such as polycyclic musks (Federle et al., 2014), hydrotropes such as sodium xylenesulfonate (Stanton et al., 2010) or various types of surfactants (Ivankovic and Hrenovic, 2010). However, the link between the impact of the individual chemical and the product that contains it have not been reported. Accordingly, the authors posit that to gain clear insight into the role that consumer choice may have requires investigation at the product level. This unique study investigates 55 PCHPs used in the bathroom in relation to their impact on the characteristics of GW and how that then impacts either treatability or direct use for garden irrigation. The PCHPs are split into three groupings: product type, branding (i.e. supermarket's own brand vs. global brands), and marketing placement (e.g. natural ingredients, organic etc.) to ascertain the impact of common drivers for consumer preference.

\section{Material and methods}

\subsection{Sampling and product characterisation}

A total of 55 PCHPs used in the bathroom and widely available on the market were used based on the categories of: shampoos $(\mathrm{SH}, \mathrm{n}=14)$, hair conditioners $(H C, n=7)$, shower gels $(S G, n=8)$, bath crèmes $(B C$, $n=3)$, baby and child products covering bath, shower and lotion products $(B C P, n=6)$, toothpastes $(T P, n=4)$, mouthwashes $(\mathrm{MW}, \mathrm{n}=6)$ and bathroom cleaners $(\mathrm{BaC}, \mathrm{n}=7)$. For each of these categories, products were also classified by brand type (global brand - GLB, supermarket owned brand - SOB) and cost of each product (in pound sterling $(f)$ per $100 \mathrm{~mL}$ ). 


\subsection{Analytical techniques}

\subsubsection{Conventional water quality parameters}

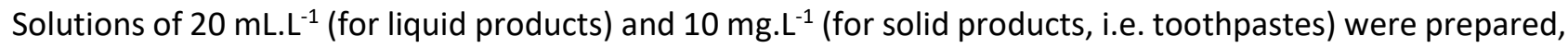
diluted if required, and used for analysis. The products doses were arbitrarily selected following a review of the literature on GW characteristics (Table S2a and S2b) and synthetic GW formulations (Table S3) to ensure the dose used here were realistic yet ensuring a quantifiable impact on GW characteristics and toxicity towards aquatic and soil microorganisms. For each product tested, conventional water quality parameters were analysed in accordance with: conductivity, $\mathrm{pH}$, turbidity, Total organic carbon (TOC), chemical oxygen demand (COD), total phosphorus (TP) and total nitrogen (TN). TOC (g. $\left.\mathrm{L}^{-1}\right)$ was analysed using a total organic carbon analyser Shimadzu TOC-5000A (Shimadzu, UK), Turbidity (NTU) using a Turbidimeter Hach 2100N and $\mathrm{pH}$ and conductivity (mS) using the Jenway $3540 \mathrm{pH}$ and conductivity meter. Merck cell tests (Merck, VWR International, Poole, UK) were used to measure COD, TN and TP $\left(\mathrm{g} \cdot \mathrm{L}^{-1}\right)$. The results are expressed as mean \pm standard deviation.

\subsubsection{Ecotoxicological impact using Microtox ${ }^{\circledR}$ and MicroResp ${ }^{T M}$}

\subsubsection{Microtox $^{\circledast}$ toxicity tests}

The acute toxicity of each product was evaluated using the Microtox ${ }^{\circledR}$ bioassay (Model 500 toxicity analyser, Azur Environmental, UK). This bioassay, using the response of the bioluminescent bacteria Vibrio fischeri to exposure to potentially toxic compounds, was performed as per the standard procedure detailed in the manufacturer's manual. For this, a working solution of luminescent bacteria was prepared by reconstituting a vial of freeze-dried Vibrio fischeri. A dilution series of the samples to be analysed was prepared in a sodium chloride solution $(\mathrm{NaCl} 2 \%)$ and luminescence was recorded after 5 minutes and 15 minutes. The luminescence recorded for each product was compared to the luminescence obtained for a bacterial control solution ( $\mathrm{NaCl} 2 \%$ ) lacking the tested compound. The half maximal effective concentration $\left(\mathrm{EC}_{50}\right)$, defined as the median concentration of a toxicant causing a $50 \%$ reduction in luminescence intensity of the Vibrio 
fischeri bacteria, was obtained from the dose-response curves for each product investigated. All sampled products were ranked in relation to standard Phenol and Linear alkylbenzene sulfonate (LAS), an anionic surfactant.

\subsubsection{MicroResp ${ }^{T M}$ tests}

Based on their impact on GW characteristics and acute toxicity found previously, 32 of the above-mentioned 55 PCHPs were selected to evaluate their short-term impact on the metabolic activity of soil microorganisms. This was done using the microplate-based respiration method MicroResp ${ }^{\mathrm{TM}}$ as described by Campbell et al. (2003). An alkaline ( $\mathrm{pH} 7.6)$, non-saline, stone-free ( $74 \%$ sand, $18 \%$ silt and $8 \%$ clay) standard uncontaminated sandy loam soil (Agriculture and Food Standards Policy Committee, 1994) was used. The soil was sieved ( $\leq$ $2 \mathrm{~mm}$ ), and its moisture content adjusted to $40-60 \%$ of the maximum water content capacity (WHCmax) before being incubated for 7 days at $25^{\circ} \mathrm{C}$. The basal respiration rate (BR), as an indicator of the of the activity of soil microorganisms, and the glucose-induced respiration (GIR) as an indicator of stimulated metabolic activity were determined using the MicroResp ${ }^{\mathrm{TM}}$ system as described in Campbell et al. (2003) and operated according to the manufacturer's manual (Macaulay Enterprises Limited, 2006). PCHPs were dosed at three concentrations defined relative to the EC50 determined during the Microtox ${ }^{\circledR}$ trials as: LOW $(0.5 \times$ average

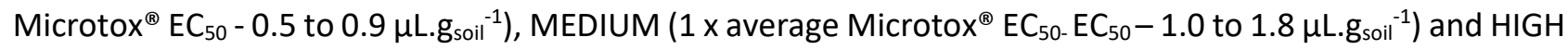
( $2.5 \times$ average Microtox ${ }^{\circledR} \mathrm{EC}_{50}-1.6$ to $\left.4.6 \mu \mathrm{L} \cdot \mathrm{g}_{\text {soil }}{ }^{-1}\right)$. The absorbance corresponding to the amount of $\mathrm{CO}_{2}$ captured by the detection microplate was read at $570 \mathrm{~nm}$ before and after $6 \mathrm{~h}$ of incubation, in absence and presence of contaminants. The absorbance values were then normalised before being converted to $\mathrm{CO}_{2}$ concentration (\%) using a calibration curve of absorbance versus $\mathrm{CO}_{2}$. Finally, the $\mathrm{CO}_{2}$ rates were converted to $\mu \mathrm{g}_{\mathrm{co2}} \cdot \mathrm{g}_{\mathrm{soi}}{ }^{-1} \cdot \mathrm{h}^{-1}$. For each product category, and also for each individual result, comparisons of the mean results from the MicroResp ${ }^{\mathrm{TM}}$ investigations in presence of PCHPs were statistically analysed against the control using Student's t-tests (two tailed, assuming unequal variance). Significance was established at $p<0.05$. A Spearman rank's correlation was also used to test the relationships between toxicity, brand type, acidity, COD/TOC ratio and unit price (i.e. price per $\mathrm{ml}$ ) for the tested products (See Supporting Information - Table S4). 


\section{Results and discussion}

\subsection{Conventional water quality parameters}

Overall the physico-chemical characteristics of the products investigated varied considerably, not only from one category to another, but also within each product category (Table 1). For instance, COD varied on average from $4.1 \pm 2.7$ g. $\mathrm{L}^{-1}$ for bathroom cleaners $(\mathrm{BaC})$ up to $44.0 \pm 31.0 \mathrm{~g} \cdot \mathrm{L}^{-1}$ for bath crèmes $(\mathrm{BC})$ with overall a minimum COD of 0.2 g. $\mathrm{L}^{-1}$ for a global brand shower cleaner and a maximum COD for a junior bath product (BCP) with $82.6 \mathrm{~g} . \mathrm{L}^{-1}$. The latter was attributed to the product containing paraffin, a mixture of highly purified hydrocarbons commonly used in cosmetics to help retain skin moisture. Similar variations in COD levels were observed within most categories with the exception of toothpastes $\left(16.7-37.2\right.$ g.. $\left.\mathrm{L}^{-1}\right)$ and bathroom cleaners (0.2-6.9 g.L $\left.{ }^{-1}\right)$. To illustrate, the different shower gel products had CODs within the range 4.5 to 75.4 g.L $\mathrm{L}^{-1}$. No apparent link could be established between branding, market placement or price indicating that there was no clear way for consumers to potentially understand the impact of their choice on the resultant GW character (SI - Figure S1, Table S4 and Table S5). Comparison to reported COD concentrations for low strength GWs reveals lower COD levels in GW (e.g. ranging from 0.07 to $1.2{\mathrm{~g} . \mathrm{L}^{-1}}^{-}$Table S2a) than for the individual product tested due to dilution effects. The final strength thus appears in relation to the combination of water consumption (Friedler and Butler, 1996) and washing habits (e.g. frequency, quantity of product used - Knops et al., 2007).

The average TOC values across the product categories ranged from $0.2 \pm 0.0 \mathrm{~g}_{\text {TOC. }} \mathrm{L}^{-1}$ for hair conditioners to $2.7 \pm 1.0 \mathrm{~g}_{\text {Tос. }} \mathrm{L}^{-1}$ for toothpastes and bath crèmes (Table 1). As for COD, TOC also varied notably within each category. For instance, within the shampoo category, the minimum TOC level, measured for a supermarket budget shampoo, was $0.1 \mathrm{~g}_{\text {Toc. }} \mathrm{L}^{-1}$ while a maximum concentration of $3.6 \mathrm{~g}_{\text {Tос. }} \mathrm{L}^{-1}$, a $3,500 \%$ increase, for a global brand shampoo for dry and frizzy hair (SI - Table S5). As an indicator of global organic pollution, the elevated TOC concentrations in the gram per litre range observed for $50 \%$ of the individual products tested and for up to $75 \%$ of the shampoos and shower gels - suggest that a regular use of these compounds, individually or in combination, is likely to play an important role in the load profile of the resulting GW.

The impact of product choice on treatability was analysed in terms of the COD:TOC ratio with high levels indicative of more easily oxidizable organics and hence better treatability than low COD/TOC which are 
associated with refractory organics (Mella et al, 2018, Hansson (2012), Guedes et al. (2003). The majority of the products tested ( 40 out of 55 ) had a COD:TOC below 20 and this included products within all the categories: bath cremes $(\mathrm{BC})$, toothpastes (TP), mouthwash (MW), bathroom cleaners $(\mathrm{BaC})$ and included the majority of the shampoos (SH) and shower gels (SG) products (Figure 1). To illustrate, average COD:TOC ratios observed for SH, MW and TP had average ratios of $11.8 \pm 5.3,11.4 \pm 3.3$ and $8.6 \pm 0.3$ respectively. Within these 40 products were 15 products that had a COD:TOC ratio below 10 and so were likely to be very difficult to oxidise. These included six shampoos, three shower gels, four toothpastes and four bathroom cleaners and covered products either in the global brands (GB) or supermarket own Brand (SOB) (SI - Table S5) . Contrastingly, the highest COD:TOC ratios observed were for hair conditioners (HC), baby and child products (BCP) with respective ratios ranging from 56 to 287 and from 13 to 120 (Figure 1). Inspection of the products ingredients' lists indicates the high ratios are associated to fatty alcohols used as emollients such as cetearyl alcohol, cetyl alcohols and stearyl alcohols that are easily oxidised. In three categories (HC, SG and BCP) the COD:TOC for individual products showed higher variability than in the other categories indicating a possible difference in treatability based on product selection. In these categories, the highest values measured were 287, 30 and 60 for an HC, a SG and a BCP respectively (Figure 1, SI-Table S5). These corresponded to supermarket own brand products (SOB) with costs between $£ 0.2$ and $£ 0.3$ per $100 \mathrm{~mL}$, amongst which a supermarket budget brand. In contrast the lowest COD:TOC ratio observed in the HC, SG and BCP categories were 56,5 and 13 . These were associated to two budget SOB products ( $£ 0.2$ per $100 \mathrm{~mL}$ for the $\mathrm{HC}$ and $£ 0.1$ per $10 \mathrm{mmL}$ for the $B C P$ ) but also one global brand SG priced $f 0.7$ per $100 \mathrm{~mL}$, showing branding and price similarity could results in high difference in COD:TOC ratios. This indicates that branding and price could not be used as consistent indicators of treatability. 
Table 1. Mean ( \pm std dev) values for different parameters by product category; ranges given in parenthesis.

\begin{tabular}{|c|c|c|c|c|c|c|c|c|c|}
\hline $\begin{array}{l}\text { Product } \\
\text { group* }\end{array}$ & Acronym & $\begin{array}{l}\text { Turbidity } \\
\text { (NTU) }\end{array}$ & $\begin{array}{c}\text { Electrical } \\
\text { conductivity }\left(E C_{w}\right) \\
\left(d S . \mathrm{m}^{-1}\right)\end{array}$ & $\mathrm{pH}$ & $\begin{array}{l}\text { COD } \\
\left(\text { g. } L^{-1}\right)\end{array}$ & $\begin{array}{l}\text { TOC } \\
\left(\text { g. } \mathrm{L}^{-1}\right)\end{array}$ & $\begin{array}{c}\mathrm{T}-\mathrm{N} \\
\left(\mathrm{mg} \cdot \mathrm{L}^{-1}\right)\end{array}$ & $\begin{array}{c}\text { T-P } \\
\left(\mathrm{mg} \cdot \mathrm{L}^{-1}\right)\end{array}$ & COD:N:P \\
\hline Shampoos & SH & $\begin{array}{c}3 \\
(<1.0-24)\end{array}$ & $\begin{array}{c}0.375 \pm 0.156 \\
(0.203-0.767)\end{array}$ & $\begin{array}{c}5.9 \pm 0.7 \\
(4.7-6.7)\end{array}$ & $\begin{array}{c}20.5 \pm 13.4 \\
(5.6-53.7)\end{array}$ & $\begin{array}{c}1.9 \pm 1.0 \\
(0.4-3.6)\end{array}$ & $\begin{array}{c}2.0 \pm 0.8 \\
(1.0-4.3)\end{array}$ & $\begin{array}{c}0.3 \pm 0.2 \\
(0.05-0.7)\end{array}$ & $\begin{array}{c}100:(0.03-0.02):(0.000- \\
0.008)\end{array}$ \\
\hline $\begin{array}{l}\text { Hair } \\
\text { conditioners }\end{array}$ & $\mathrm{HC}$ & $\begin{array}{c}32 \\
(7-64) \\
\end{array}$ & $\begin{array}{c}0.004 \pm 0.005 \\
(0.001-0.015)\end{array}$ & $\begin{array}{c}4.5 \pm 0.5 \\
(3.7-5.1)\end{array}$ & $\begin{array}{c}20.2 \pm 20.6 \\
(5.9-65.7)\end{array}$ & $\begin{array}{c}0.2 \pm 0.0 \\
(0.1-0.2)\end{array}$ & $\begin{array}{c}2.0 \pm 0.7 \\
(1.1-2.8) \\
\end{array}$ & $\begin{array}{c}0.1 \pm 0.1 \\
(0.04-0.3)\end{array}$ & $\begin{array}{c}100:(0.02-0.03):(0.000- \\
0.002)\end{array}$ \\
\hline Shower gels & SG & $\begin{array}{c}4 \\
(<1-20) \\
\end{array}$ & $\begin{array}{c}0.252 \pm 0.202 \\
(0.004-0.680)\end{array}$ & $\begin{array}{c}5.4 \pm 0.8 \\
(4.5-6.7) \\
\end{array}$ & $\begin{array}{r}29.4 \pm 27.5 \\
(4.5-75.4) \\
\end{array}$ & $\begin{array}{c}1.6 \pm 0.9 \\
(0.8-3.5) \\
\end{array}$ & $\begin{array}{c}1.0 \pm 0.3 \\
(0.6-1.4) \\
\end{array}$ & $\begin{array}{c}0.5 \pm 0.4 \\
(0.1-1.1) \\
\end{array}$ & $\begin{array}{c}100:(0.00-0.02):(0.000- \\
0.024)\end{array}$ \\
\hline Bath Cremes & BC & $\begin{array}{c}4.2 \\
(<1-12)\end{array}$ & $\begin{array}{c}0.366 \pm 0.054 \\
(0.304-0.402)\end{array}$ & $\begin{array}{c}5.3 \pm 0.8 \\
(4.6-6.1)\end{array}$ & $\begin{array}{c}44.0 \pm 31.0 \\
(11.5-73.2)\end{array}$ & $\begin{array}{c}2.7 \pm 2.0 \\
(0.7-4.7)\end{array}$ & $\begin{array}{c}2.0 \pm 1.3 \\
(1.1-3.6)\end{array}$ & $\begin{array}{c}0.3 \pm 0.2 \\
(0.1-0.4)\end{array}$ & $\begin{array}{c}100:(0.00-0.03):(0.000- \\
0.001)\end{array}$ \\
\hline $\begin{array}{l}\text { Baby } \& \text { child } \\
\text { products** }\end{array}$ & BCP* & $\begin{array}{c}158 \\
(<1.0- \\
949) \\
\end{array}$ & $\begin{array}{c}0.129 \pm 0.193 \\
(0.001-0.478)\end{array}$ & $\begin{array}{c}6.5 \pm 1.1 \\
(5.4-8.3) \\
\end{array}$ & $\begin{array}{l}30.7 \pm 35.1 \\
(5.5-82.6)\end{array}$ & $\begin{array}{c}0.8 \pm 0.7 \\
(0.1-2.1)\end{array}$ & $\begin{array}{c}1.8 \pm 0.6 \\
(1.8-2.7)\end{array}$ & $\begin{array}{c}0.4 \pm 0.4 \\
(0.0-0.9)\end{array}$ & $\begin{array}{c}100:(0.00-0.05):(0.000- \\
0.001)\end{array}$ \\
\hline Toothpastes & TP & $\begin{array}{c}115 \\
(2.7-349)\end{array}$ & $\begin{array}{c}0.022 \pm 0.014 \\
(0.010-0.037)\end{array}$ & $\begin{array}{c}7.2 \pm 0.5 \\
(6.7-7.6)\end{array}$ & $\begin{array}{c}23.1 \pm 9.7 \\
(16.7-37.2)\end{array}$ & $\begin{array}{c}2.7 \pm 1.0 \\
(2.0-4.2)\end{array}$ & $\begin{array}{c}3.3 \pm 0.9 \\
(2.5-4.5)\end{array}$ & $\begin{array}{c}3.2 \pm 5.2 \\
(0.2-11.0)\end{array}$ & $\begin{array}{c}100:(0.01-0.03):(0.001- \\
0.066)\end{array}$ \\
\hline Mouthwash & MW & $\begin{array}{c}0.02 \\
(<1-<1)\end{array}$ & $\begin{array}{c}0.009 \pm 0.006 \\
(0.001-0.016)\end{array}$ & $\begin{array}{c}5.9 \pm 1.0 \\
(4.3-7.9)\end{array}$ & $\begin{array}{c}11.3 \pm 6.1 \\
(2.0-20.6)\end{array}$ & $\begin{array}{c}0.9 \pm 0.4 \\
(0.4-1.6)\end{array}$ & $\begin{array}{c}2.6 \pm 1.1 \\
(1.6-4.3)\end{array}$ & $\begin{array}{c}0.2 \pm 0.2 \\
(0.0-0.5)\end{array}$ & $\begin{array}{c}100:(0.01-0.22):(0.000- \\
0.027)\end{array}$ \\
\hline $\begin{array}{l}\text { Bathroom } \\
\text { cleaners }\end{array}$ & $\mathrm{BaC}$ & $\begin{array}{c}5 \\
(<1-30)\end{array}$ & $\begin{array}{c}0.177 \pm 0.180 \\
(0.046-0.537)\end{array}$ & $\begin{array}{c}8.3 \pm 2.9 \\
(4.0-11.8)\end{array}$ & $\begin{array}{l}4.15 \pm 2.74 \\
(0.2-6.9)\end{array}$ & $\begin{array}{c}0.4 \pm 0.3 \\
(0.2-0.8)\end{array}$ & $\begin{array}{c}1.5 \pm 0.9 \\
(0.3-2.6)\end{array}$ & $\begin{array}{c}0.4 \pm 0.5 \\
(0.03-1.55)\end{array}$ & $\begin{array}{c}100:(0.01-1.11):(0.000- \\
0.039)\end{array}$ \\
\hline
\end{tabular}

* The results compiled in this table were generated using solutions of $20 \mathrm{~mL}^{-1}$ (for liquid products) and 10 mg. $\mathrm{L}^{-1}$ (for solid products, i.e. toothpastes)

** The baby and child products category covers baby/junior bath and shower products, and baby lotion. 


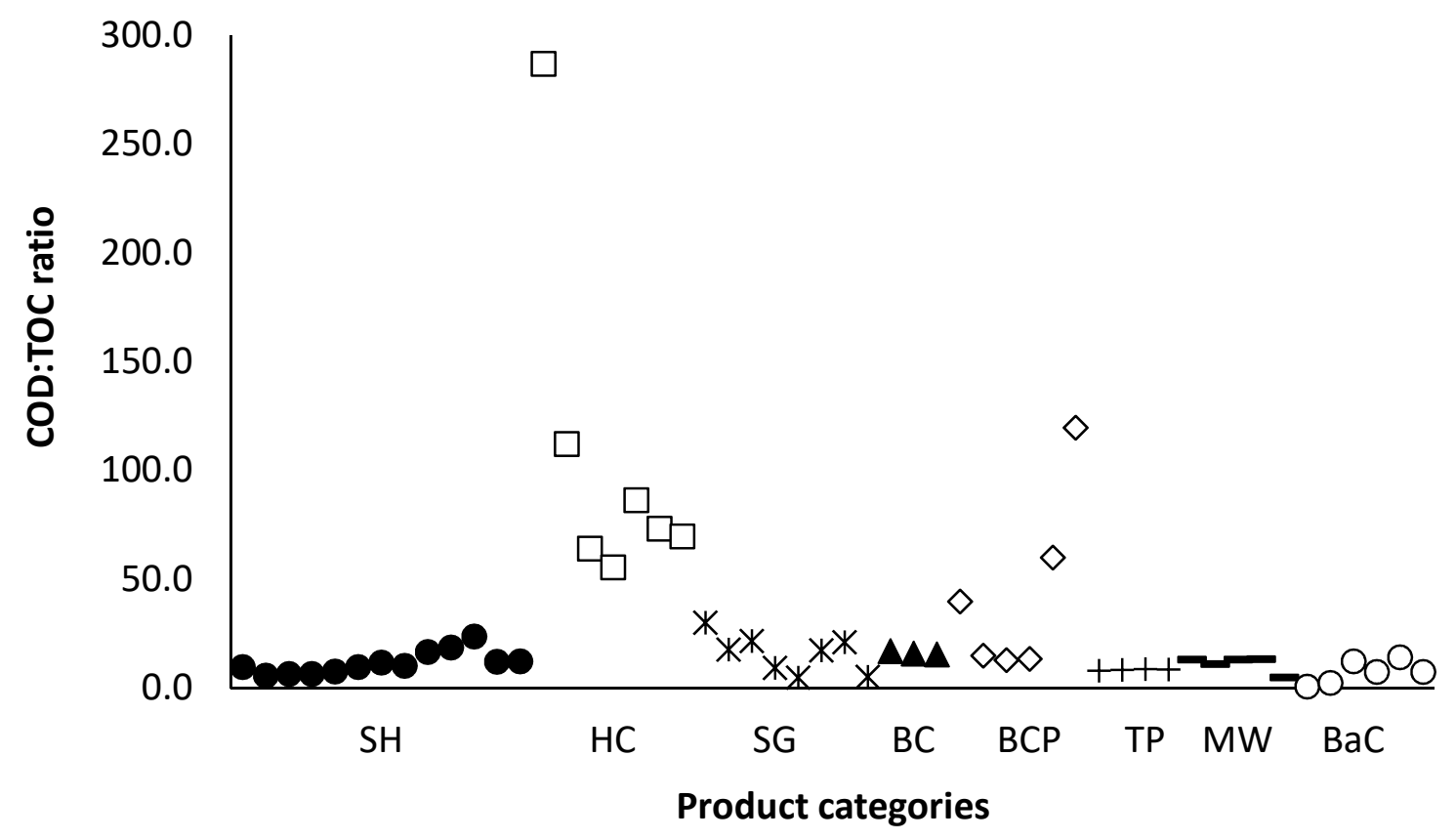

Figure 1. COD to TOC ratios of individual products by product category.

In terms of macronutrients, the levels of nitrogen $(\mathrm{N})$ and phosphorus $(\mathrm{P})$ were low across the personal care product categories with values typically in the region of $2.0 \mathrm{mgN}_{\mathrm{N}} \mathrm{L}^{-1}$ for nitrogen and $0.3 \mathrm{mg}_{\mathrm{P} . \mathrm{L}^{-1}}$ for phosphorus (Table 1). This is congruent with the fact that the use of P in PCHP is typically limited to toothpaste with varying contents between 2 and $14 \mathrm{mg}_{\mathrm{p}}$ per $\mathrm{g}$ of product (Comber et al., 2013). The current results mirror this level of variation at between 0.2 and $11.0 \mathrm{mg}_{\mathrm{P} . \mathrm{L}^{-1}}$ with an overall average of $3.2 \pm 5.2 \mathrm{mg}_{\mathrm{P} . \mathrm{L}^{-1}}$. Data on macronutrients were expressed in terms of the COD:N:P ratio which is commonly used as an indication of treatability with biological processes (Jefferson et al., 2001). The COD:N:P ratios were low with example ratios of 100:0.10:0.002 for shampoos, 100:0.01:0.007 for shower gels, 100:0.24:0.01 for bathroom cleaners (Table 1). In their review of GW recycling treatment options, Pidou et al., (2007) reported considerably higher COD:N:P ratios for bath, shower and hand washing basins of respectively 100:2.25:0.06, 100:2.91:0.05 and 100:1.77:0.06, suggesting these higher ratios were the result of higher levels of nitrogen and phosphorus residues of human origin from bathing and washing activities.

Overall, this indicates that products used in the bathroom are unlikely to result in a GW with a COD:N:P ratio equal or higher than the optimum ration of 100:5:1 for biological treatment ( Jefferson et al., 2004). As shown by Jefferson et al. (2001), this suggests limited biological treatment of GW without $\mathrm{N}$ and P adjustment. This 
observation has also been made for GW from different sources within the household as well as on a larger spatial scale (Eriksson et al., 2002; Pidou et al., 2008). Despite suggesting some limitations towards biological treatment, the macronutrients deficiency of GW does not limit its treatability. In fact, several studies have successfully demonstrated that bathroom GW was treatable using a range of technologies involving chemical, physical as well as biological processes with for example membrane bioreactors, rotating biological contactors and constructed wetlands (Pidou et al., 2007).

The $\mathrm{pH}$ values across all categories were predominantly acidic with $72 \%$ of the measured values below 6.5 , with a minimum of 3.5 for one $\mathrm{HC}$ (Table 1 ). In fact, $78 \%$ of the products tested have $\mathrm{pH}$ values outside the recommended range for irrigation of 6.5-8.5 to avoid any potential impact on soil properties (Ayers and Westcot, 1985). In contrast, $100 \%$ of the products had electrical conductivity $\left(E C_{w}\right)$, values below those identified as having detrimental effects on plants and soil (Ayers and Westcot, 1985) with moderate effects identified once the $\mathrm{ECW}$ exceeds $0.7 \mathrm{dS} \cdot \mathrm{m}^{-1}$ and detrimental once it exceeds $3.0 \mathrm{dS} \cdot \mathrm{m}^{-1}$. Average values ranged from $0.004 \pm 0.005 \mathrm{dS} . \mathrm{m}^{-1}$ for $\mathrm{HC}$ to $0.375 \pm 0.156 \mathrm{dS} . \mathrm{m}^{-1}$ for shampoos, while the BaC category exhibited an average value of $0.177 \pm 0.180 \mathrm{dS} \cdot \mathrm{m}^{-1}$ (Table 1). Overall, once diluted no PCHPs appear to pose a risk for irrigation based on $\mathrm{pH}$ or $\mathrm{ECW}$ such that any detrimental impact will be based on the toxicity to soil microflora.

\subsection{Microtox toxicity}

A comparison of the toxicities obtained by category shows the shampoos (SH) to be on average the most toxic requiring concentrations of only 26.5 and $13.0 \mu \mathrm{L} . \mathrm{L}^{-1}$ to reach the $\mathrm{EC}_{50}$ after respectively 5 and $15 \mathrm{~min}$ of exposure (Figure 2). Further, the median $\mathrm{EC}_{50}$ for the category was below that of linear alkylbenzene sulfonate (LAS) which was being used as benchmark as it is the most common anionic surfactant used in the production of detergents and soaps worldwide (Bergé et al., 2018). Overall, after $5 \mathrm{~min}$ of exposure (Figure 2a), the $\mathrm{EC}_{50}$ values ranged from $0.4 \mu \mathrm{L} . \mathrm{L}^{-1}$ for the most toxic product (a global brand shampoo) to $1,841.0$ $\mu \mathrm{L} . \mathrm{L}^{-1}$ for the least toxic product (a budget supermarket hair conditioner). After 15 min (Figure $2 \mathrm{~b}$ ), these values dropped from $0.2 \mu \mathrm{L} . \mathrm{L}^{-1}$ to $1,423.0 \mu \mathrm{L} . \mathrm{L}^{-1}$ illustrating an increase in toxicity with exposure time in 
agreement with previous reported $\mathrm{EC}_{50-5 \mathrm{~min}}: \mathrm{EC}_{50-15 \mathrm{~min}}$ ratio of 1:0.56 for the anionic surfactant sodium lauryl sulphate (Dutka et al., 1983). This compares to a $\mathrm{EC}_{50-5 \mathrm{~min}} \mathrm{EC}_{50-15 \mathrm{~min}}$ ratio of 1:0.55 for the standard compound linear alkylbenzene sulfonate (LAS) and suggests a slower mode of action for surfactant which are core ingredients of personal care products and detergents formulations with contents typically varying from 10 to $20 \%$ in shampoos and up to $40 \%$ in detergents (Yang, 2017).

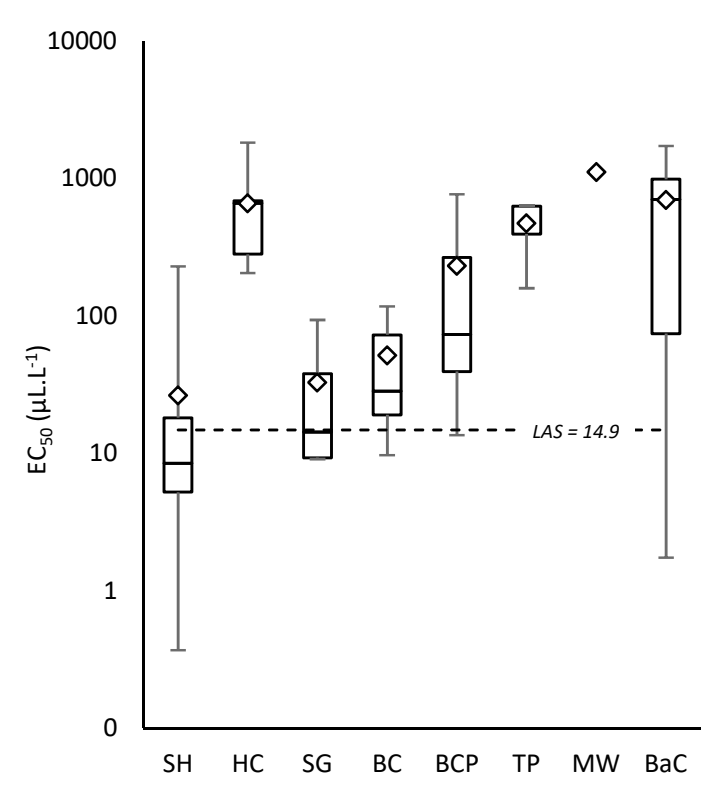

(a)

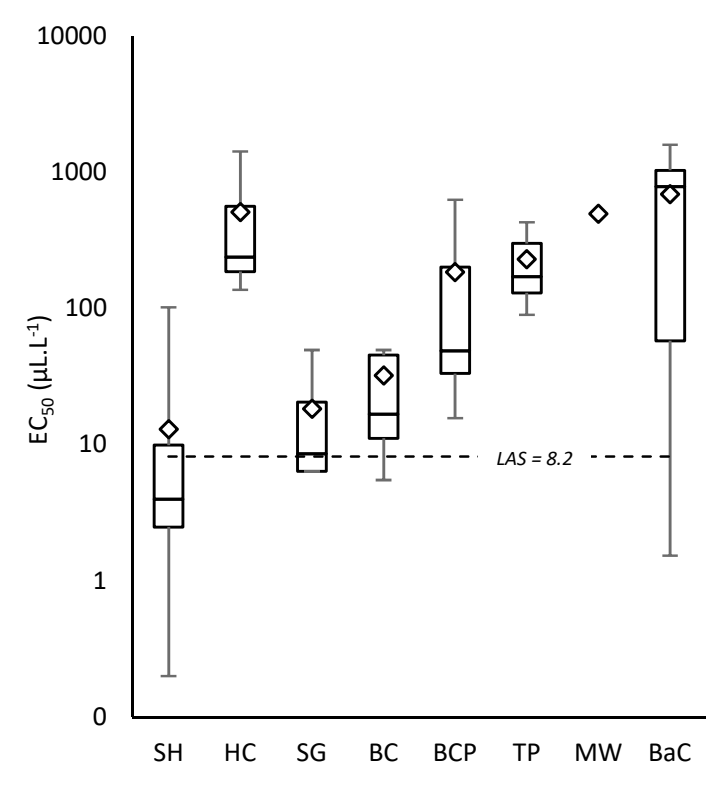

(b)

Figure 2. Boxplots of Microtox ${ }^{\circledR}$ toxicities by product category after (a) $5 \mathrm{~min}$ of exposure and (b) $15 \mathrm{~min}$ of exposure.

For each category, the lower boundary of the box-plot represents the $25^{\text {th }}$ percentile values and the upper boundary the $75^{\text {th }}$ percentile values; the horizontal line the box indicates the median and the whiskers ranges from the minimum and maximum values. The data points represent the average. (note LAS stands for linear alkyl benzenesulfonate).

The Microtox ${ }^{\circledR}$ results within each category were extremely variable. For instance, the $\mathrm{EC}_{50}$ of the shampoos (SH) tested after $5 \mathrm{~min}$ of exposure varied from $0.4 \mu \mathrm{L} . \mathrm{L}^{-1}$ for a global brand anti-dandruff shampoo to 230.0 $\mu \mathrm{L} . \mathrm{L}^{-1}$ for a supermarket own brand (SOB) budget shampoo. The highest $\mathrm{EC}_{50}$ variations observed within a category whether after 5 or $15 \mathrm{~min}$ of exposure was for the bathroom cleaners $(\mathrm{BaC})$ with values ranging from $1.7 \mu \mathrm{L} . \mathrm{L}^{-1}$ for the most toxic product, an eco-friendly branded cleaning product for shower and bath, to 1735.3 
$\mu \mathrm{L} . \mathrm{L}^{-1}$ for a global brand shower cleaning product. For $\mathrm{SH}$, an analysis of possible trends between their toxicity as $\mathrm{EC}_{50}$, their $\mathrm{COD}$ as an indicator of organic pollution, brand type and price of the product was conducted as there were sufficient individual products (Figure 3). Overall, as for other categories (data not shown), no particular trend could be found between COD and toxicity. When looking at toxicity and price, the SOB shampoos which are on average lower cost ( $f 0.6$ per $100 \mathrm{~mL}$ ) than global brand shampoos (GB) ( $f 1.7$ per $100 \mathrm{~mL}$ ), showed higher variability in terms of toxicity. For instance, one compound (SOB2) was the second most toxic shampoo tested across the shampoo category with an $\mathrm{EC}_{50}$ value of $2.8 \mu \mathrm{L} . \mathrm{L}^{-1}$ with another the least toxic shampoo (SOB3) with an $\mathrm{EC}_{50}$ value of $230 \mu \mathrm{L} \cdot \mathrm{L}^{-1}$. In the latter case, this shampoo was also the least expensive of all, with a price of $£ 0.3$ per $100 \mathrm{~mL}$. It should be noted that the shampoo GB9 was labelled as containing " $100 \%$ natural fragrances, natural plant extracts, parabens free" with mention of the term "vegan" resulted in an $\mathrm{EC}_{50}$ of $18.2 \mu \mathrm{L} . \mathrm{L}^{-1}$ after $5 \mathrm{~min}$ of exposure. Overall across categories, eco-labelled products or products composed of ingredients of natural origins and parabens free, were found to be no less toxic than supermarket own brands or other commercially available brands. In fact, no specific trend between brand labelling and toxicity could be clearly established indicating that it would be extremely difficult for consumers to make informed decisions about product selection relative to reuse of GW. This is in agreement with the results observed by Knops (2010) who investigated the effect of 32 PCHPs (including shampoo, shower gels, all purposes cleaners, washing powders and washing up liquid) categorised by cost and ecological credentials on biological systems using Microtox and respirometry as toxicity assessment methods. They concluded that despite some variations in toxicity within each product category, no correlations between toxicity and product type, cost or ecological status (environmentally friendly vs. non environmentally friendly) could be found. 


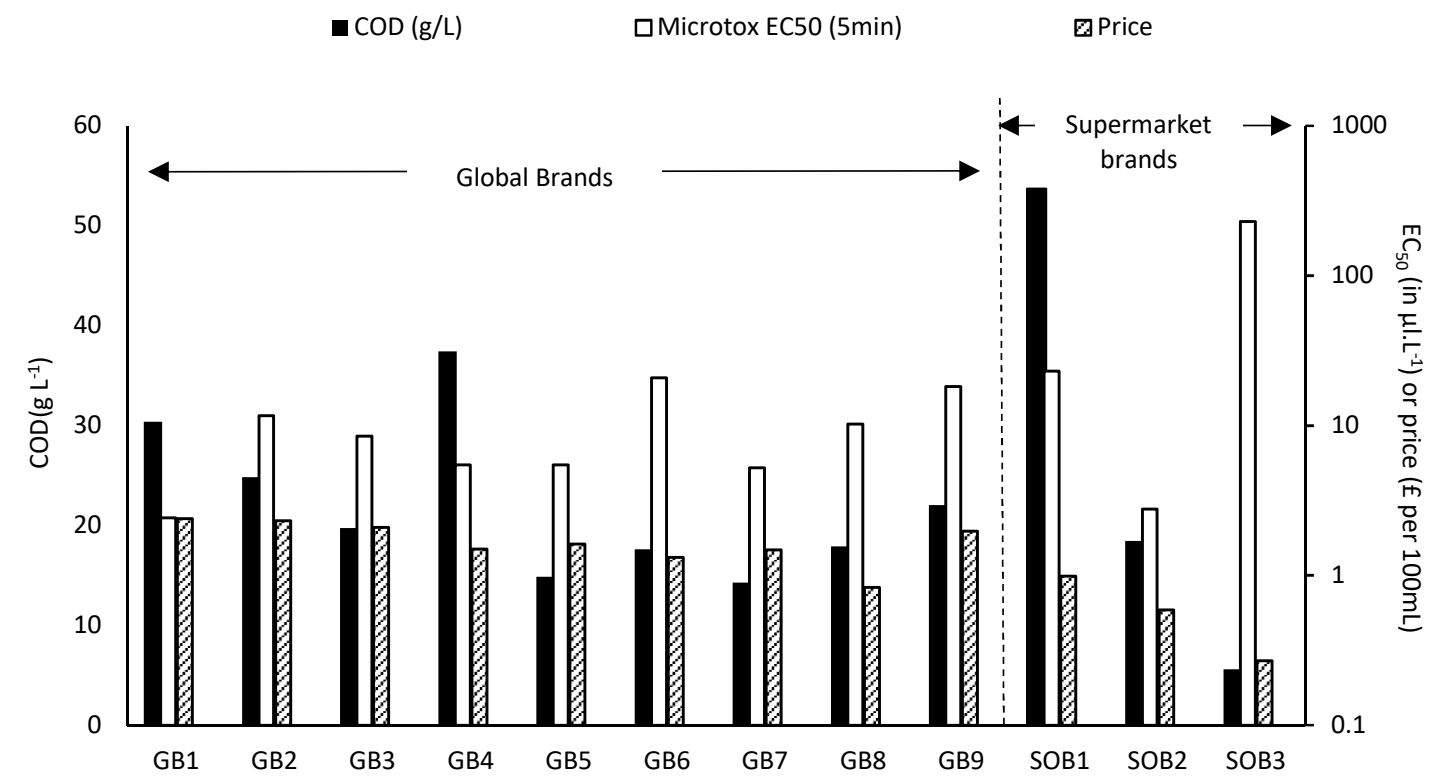

Figure 3. $\mathrm{COD}$, Microtox ${ }^{\circledR} \mathrm{EC} \mathrm{C}_{50}(5 \mathrm{~min})$ and price ( $\mathrm{f}$ per $100 \mathrm{~mL}$ ) for shampoos. GB stands for "global brand" and SOB for "supermarket owned brand".

\subsection{Impact on the metabolic activity of soil microorganisms}

Addition of all doses and all products onto the soil, with the exception of shower gels, caused metabolic stimulation, measured as an increase in basal respiration (BR) of the soil microorganisms when compared to the control (Figure 4). In the case of a high dose of shower gel, $2.8 \mu \mathrm{L} . \mathrm{g}^{-1}$ soil, the BR decreased from $3.13 \pm$ $0.88 \mu \mathrm{g}_{\mathrm{co2}} \cdot \mathrm{g}^{-1} \cdot \mathrm{h}^{-1}$ to $3.09 \pm 0.92 \mu \mathrm{g}_{\mathrm{co2}} \cdot \mathrm{g}^{-1} \cdot \mathrm{h}^{-1}$ and was not statistically significant $(p=0.89)$ (SI - Table S6). Further, when looking at the impact of individual products within each category, a decrease in BR between the control and one of the added doses of PCHP was only observed on eight occurrence within five of the seven categories. These were observed in the following categories: shampoos, ( $n=2$ out of 4$)$, hair conditioners ( $n=1$ out of 6 ), shower gels ( $n=3$ out of 4 ), mouth washes ( $n=1$ out of 6 ) and bathroom cleaners ( $n=1$ out of 4). For instance, in the shower gel category (SG), the addition of a high dose of SG1 (i.e. $2.8 \mu$ L.gsoil ${ }^{1}$ ) resulted in a BR of $3.77 \pm 0.06 \mu \mathrm{gcos}_{\mathrm{cog}} \cdot \mathrm{g}^{-1} \cdot \mathrm{h}^{-1}$ as opposed to $3.96 \pm 0.13 \mu \mathrm{g}_{\mathrm{co2}} \cdot \mathrm{g}^{-1} \cdot \mathrm{h}^{-1}$ for the control (Figure 5). This decrease was found to be statistically significant $(p=0.02)$, suggesting an inhibitory effect of that specific shower gel on soil microorganisms. Similarly, for SG3, the addition of a high dose of product resulted in a significant $12 \%$ decrease in BR when compared to the control $(p=0.01)$. Interestingly, for that same product, 
the addition of a medium dose (i.e. $1.4 \mu \mathrm{L} \cdot \mathrm{g}_{\text {soil }}{ }^{-1}$ ) caused a significant metabolic stimulation with a $20 \%$ increase in BR.

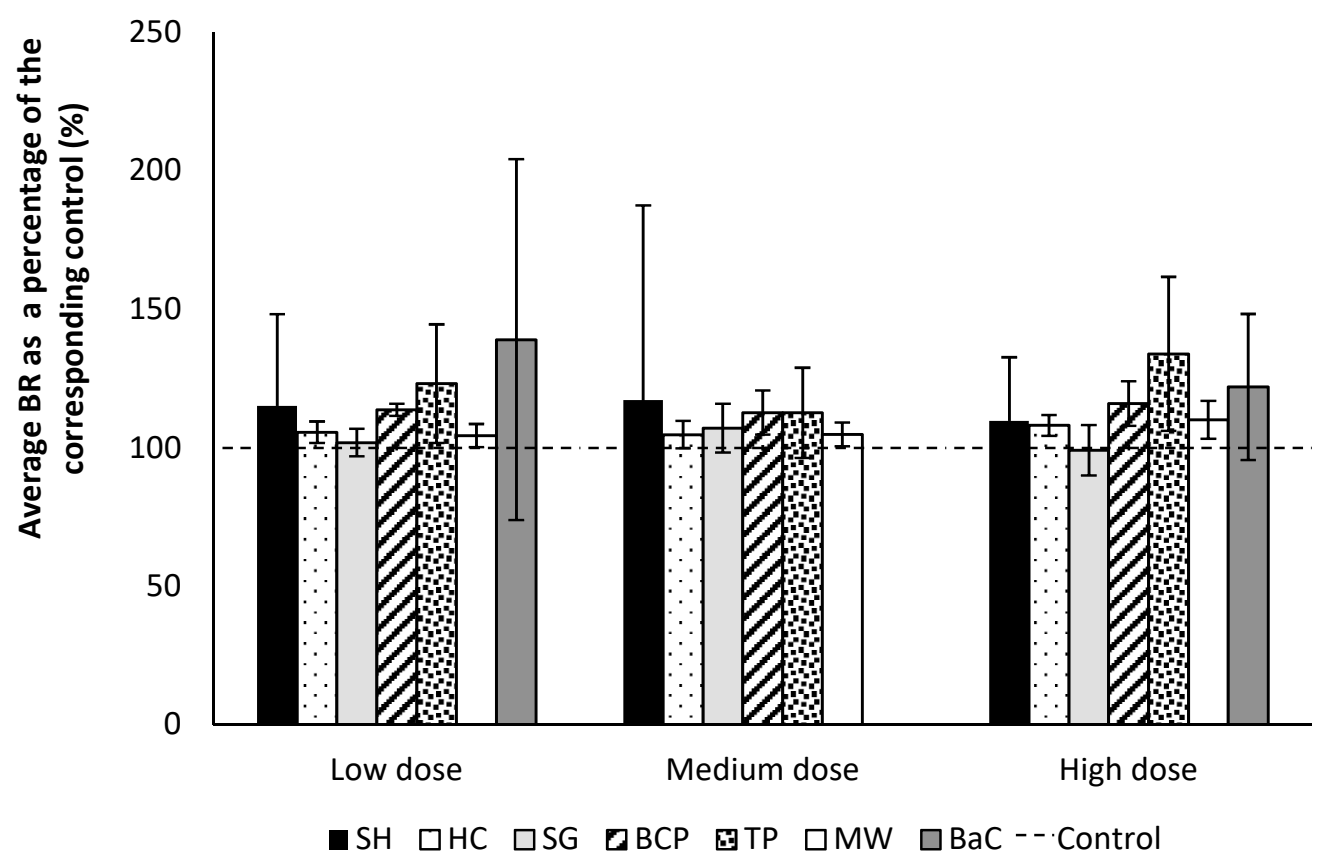

Figure 4. Average basal respiration (BR) per product category as a percentage of the corresponding control (\%).

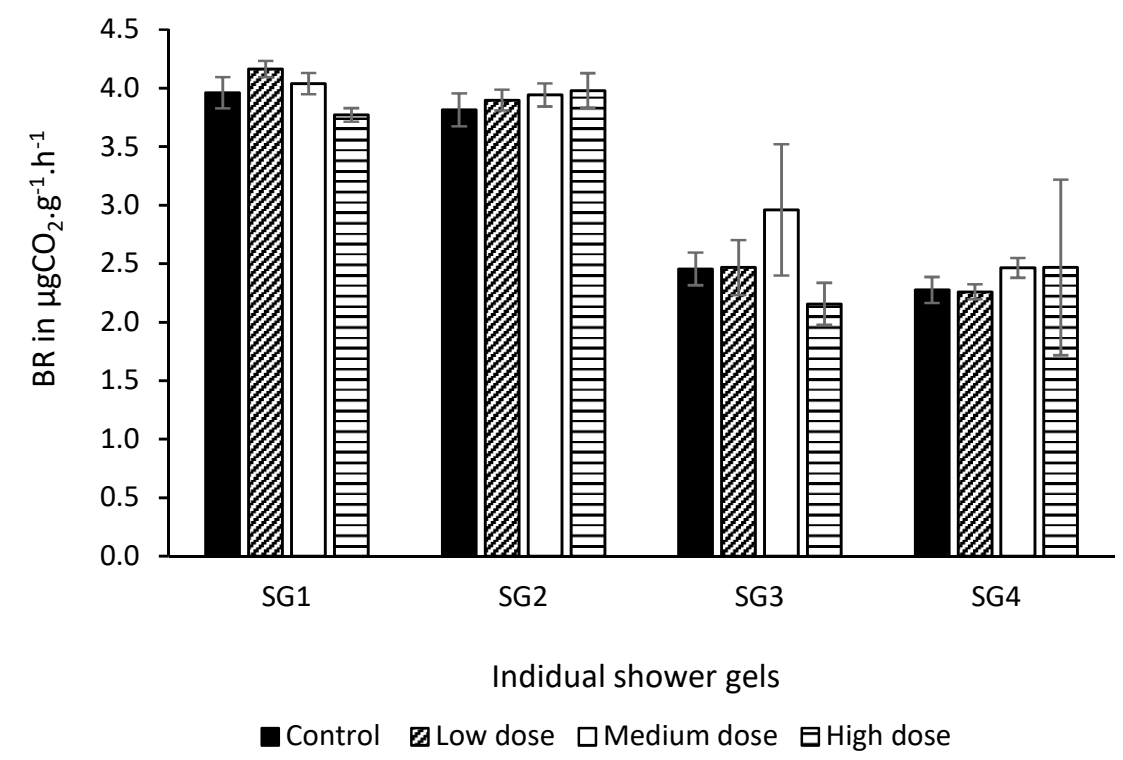

Figure 5. Average basal respiration of soil (BR - in $\left.\mu g_{\text {cor }} \cdot g^{-1} \cdot h^{-1}\right)$ exposed to low $\left(0.7 \mu \mathrm{g} \cdot \mathrm{L}^{-1}\right)$ medium $\left(1.4 \mu \mathrm{g} \cdot \mathrm{L}^{-}\right.$ $\left.{ }^{1}\right)$ and high doses $\left(2.8 \mu \mathrm{g} \cdot \mathrm{L}^{-1}\right)$ of four shower gels. 
Overall it should be noted that a large majority of the products tested (24 out of 32 ) caused a stimulation response from the soil microorganisms. This is attributed to a combination of direct carbon utilisation or as a result of stress response (Fuller, 2004). This was explored by also performing the tests including adding glucose as a readily available carbon source to measure glucose-induced respiration (GIR). In these tests, an average decrease in GIR was observed in four categories as opposed to one category when glucose was not used (i.e. BR). However, these were not statistically significant ( $p>0.05$, SI - Table S6 and Figure S1). Fourteen products resulted in a lower GIR than the control across the categories. But only two products showed a significant inhibition effect. These were a shampoo, for which a $22 \%$ drop in GIR at a low dose (i.e. $0.9 \mu$ L.gsoil

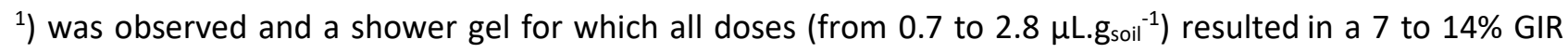
decrease when compared to the control.

Overall, based solely on the MicroResp ${ }^{\mathrm{TM}}$ results, short-term discharge of treated GW, independent of consumer product selection, is unlikely to have a negative impact on soil microbial activity. In their recent study on the long-term effect of GW disposal to soil, Siggins et al. (2016) found that untreated GW disposal to soil over periods of 8 to 18 years increased microbial content and activity measured as increases in microbial biomass and basal respiration, and had a moderate impact on the soil environment. They concluded that GW recycling may be beneficial to soil health and plant growth but also stressed that other parameters such as $\mathrm{pH}$, phosphate, salt adsorption ratios and pathogen indicators must be taken into account when planning GW recycling for irrigation.

Comparison of individual toxicity results obtained using Microto ${ }^{\circledR}$ and MicroResp ${ }^{\mathrm{TM}}$ showed no apparent correlation. To illustrate, despite being the most toxic category according to Microtox ${ }^{\bullet}$ results, the shampoos tested using MicroResp $\mathrm{p}^{\mathrm{TM}}$ either caused an increased microbial activity, or when a decrease in respiration was observed, the effect was found not to be significant when measured as BR, and significant only once when measure as GIR. Overall, the results revealed that Microtox ${ }^{\circledR}$ seemed a more sensitive measure of toxicity than MicroResp ${ }^{\mathrm{TM}}$ as indicated by the very low concentrations capable of producing a toxic effect on Microtox ${ }^{\circledR}$ test species (Vibrio fischeri). It should be noted that the risks described in the current study relate 
to untreated GW, and that treatment will lower the risks associated with any specific pollutant. Interestingly, the order of decreasing $\left(\right.$ Microtox $^{\circledR}$ ) toxicity for some personal care products (Shampoos > Shower Gels > Bath Crèmes), is a mirror of the toxicity pattern in real GW (washing and shower > kitchen > bathtub and hand basin) as reported by Eriksson et al. (2006).

\section{Conclusions}

This study has demonstrated the high variability of the characteristics of PCHPs available to consumers that potential go into the production of GW. This is seen both between and within categories of products, but no clear trend could be observed based on factors that that normally determine consumer choice of product such as branding and price. Importantly, products labelled as eco-friendly were not seen to be less polluting or indeed less toxic. Ultimately, this means that consumer have no clear way of understanding how their selection will impact GW treatment and reuse. However, actual usage patterns of PCHPs (e.g. volumes, frequency) combined with water usage could be influential factors, and further research on this aspect is required.

The major impacts were seen in relation to the pollution load and the physico-chemical characteristics and were sufficient that they could result in poorly treated GW with deteriorated aesthetic qualities. Importantly, this will also likely impact associated disinfection stages through either through exerting addition disinfectant demand or shielding potential pathogens. Overall, the work has revealed that product selection needs to considered in combination with the amounts of both product and water that make up the GW when designing and operating GW treatment systems. Interestingly, no adverse impacts could be seen with regards to soil health highlighting the potential value of using nature based solutions for the treatment of GW such as cascading vertical flow wetlands (Kadewa et al., 2010).

\section{Acknowledgement}

The authors wish to thank the Beit Trust for their financial and technical support.

Data underlying this paper can be accessed at: https://doi.org/10.17862/cranfield.rd.12356600 


\section{References}

Agriculture and Food Standards Policy Committee, (1994). Specifications for Topsoil: BS 3882, British Standard ed. BSI 04-1999, UK.

APHA (1998) Standard methods for the examination of water and wastewater, 20th ed. American Public Health Association, Washington, DC, USA

Asano, T., Burton, F.L., Leverenz, H.L., Tsuchihashi, R. and Tchobanoglous, G. (2007) Water Reuse: Issues, Technologies, and Applications. Metcalf \& Eddy/AECOM \& McGraw-Hill, New York, USA.

Ayers, R.S. and Westcot, D.W. Water Quality for Agriculture; Food and Agriculture Organization of the United Nations: Rome, Italy, 1985. Available at: http://www.fao.org/3/t0234e/t0234e00.htm. [date accessed: 15 January 2020 ]

Bergé, A., Wiest, L., Baudot, R., Giroud, B. and Vulliet, E. (2018) Occurrence of multi-class surfactants in urban wastewater: contribution of a healthcare facility to the pollution transported into the sewerage system, Environmental Science and Pollution Research, 25 (10), p. 9219-9229.

Cosmetics Europe (2017) Socio-Economic Development \& Environmental Sustainability: The European Cosmetics Industry's Contribution 2017. Available at: https://www.cosmeticseurope.eu/library/6 [date accessed: 15 Dec 2019]

Campbell, C.D., Chapman, S.J., Cameron, C.M., Davidson, M.S. and Potts, J.M. (2003). A rapid microtiter plate method to measure carbon dioxide evolved from carbon substrate amendments so as to determine the physiological profiles of soil microbial communities by using whole soil. Applied and Environmental Microbiology, 69 (2003), p. 3593-3599

Comber, S., Gardner, M., Georges, K., Blackwood, D. and Gilmour, D. (2013). Domestic source of phosphorus to sewage treatment works. Environmental Technology, 34(10), p. 1349-1358

Dhillon, G.S., Kaur, S., Pulicharla, R., Brar, S.K., Cledón, M., Verma, M. and Surampalli, R.Y. (2015) Triclosan: Current status, occurrence, environmental risks and bioaccumulation potential, International Journal of Environmental Research and Public Health, 12 (5), p. 5657-5684. 
Dutka B.J., Nyholm N. and Petersen J. (1983) Comparison of several microbiological toxicity screening tests, Water Research, 17(10), 1363-1368.

Eriksson, E., Auffarth, K., Henze, M. and Ledin, A. (2002). Characteristics of grey wastewater. Urban Water, 4, p. 85-104.

Eriksson, E., Baun, A., Henze, M. and Ledin, A. (2006). Phytotoxicity of grey wastewater evaluated by toxicity tests. Urban Water, 3(1), p. 13-20.

Federle, T., Sun, P., Dyer, S. and Kiel, B. (2014) Probabilistic assessment of environmental exposure to the polycyclic musk, HHCB and associated risks in wastewater treatment plant mixing zones and sludge amended soils in the United States. Science of the Total Environment, 493, p. 1079-1087.

Friedler, E. and Butler, D. (1996). Quantifying the inherent uncertainty in the quantity and quality of domestic wastewater Water Science and Technology, 33(2), p. 65-78.

Fuller, M.E. (2004) Pollutants - Effects on Microorganisms. Encyclopaedia of Soils in the Environment, 4, p. 258-264.

Guedes, A.M.F.M., Madeira L.M.P., Boaventuraa, R.A.R. and Costa, C.A.V. (2003) Fenton oxidation of cork cooking wastewater-overall kinetic analysis. Water Research, 37, 3061-3069.

Hansson, H. (2012) Photo-fenton and fenton oxidation of recalcitrant industrial wastewater. In: William Hogland (ed.), Eco-Tech 2012 (pp. 187). Linnaeus University. Available at: https://www.divaportal.org/smash/get/diva2:677059/FULLTEXT01.pdf . [Date accessed: 20 July 2020].

Hernández-Leal, L.H., Vieno, N., Temmink, H., Zeeman, G. and Buisman, C.J.N. (2010) Occurrence of xenobiotics in gray water and removal in three biological treatment systems. Environmental Science and Technology, 2010, 44 (17), 6835-6842.

Ivanković, T. and Hrenović, J. (2010) Surfactants in the environment. Arhiv za Higijenu Rada i Toksikologiju, $61(1)$, p. $95-110$. 
Jefferson, B., Laine, A., Stephenson, T. and Judd, S. (2001). Advanced biological unit processes for domestic water recycling. Water Science and Technology, 43(10), p. 211-218.

Jefferson, B., Palmer, A., Jeffrey, P., Stuetz, R. and Judd, S. (2004). Grey water characterisation and its impact on selection and operation of technologies for urban reuse Water Science and Technology, 50(2), p. 157-164.

Kadewa, W. W., Le Corre, K., Pidou, M., Jeffrey, P.J. and Jefferson, B. (2010) Comparison of grey water treatment performance by a cascading sand filter and a constructed wetland. Water Science and Technology, 62(7), 1471-1478.

Knops, G., Pidou, M., Kadewa, W., Soares, A., Jeffrey, P. and Jefferson, B. (2007). Reuse of urban water: Impact of product choice. In: Dangerous Pollutants (Xenobiotics) in Urban Water Cycle, Springer, Netherlands, Hlavinek, P., Bonacci, O., Marsalek, J., et al (eds.), Lednice, Czech Republic, May 3-7 2007, p. $13-22$.

Knops, G. (2010) Impact of Chemical Shock Loads on a Membrane Bioreactor for Urban Water Reuse (PhD thesis, Cranfield University, Cranfield, UK). Accessible at: https://core.ac.uk/reader/140237 [date accessed: 10 July 2020].

Macaulay Enterprises Limited. (2006). MicroResp ${ }^{\mathrm{TM}}$ Technical Manual: A versatile soil respiration system. Macaulay Research Institute, Aberdeen, UK.

Mella, B., Barcellos, B., Costa, D. and Gutterres, M. (2018). Treatment of Leather Dyeing Wastewater with Associated Process of Coagulation-Flocculation/Adsorption/Ozonation. Ozone: Science \& Engineering, 40 (2), 133-140.

Noutsopoulos, C., Andreadakis, A., Kouris, N., Charchousi, D., Mendrinou, P., Galani, A., Mantziaras, I., and Koumaki, E. (2018). Greywater characterization and loadings - Physicochemical treatment to promote onsite reuse. Journal of Environmental Management, 216, p. 337-346.

Oktor, K. and Çelik, D. (2019). Treatment of wash basin and bathroom greywater with Chlorella variabilis and reusability. Journal of Water Process Engineering, 31, art. no. 100857. 
Oteng-Peprah, M., Acheampong, M.A. and deVries, N.K. (2018). Greywater Characteristics, Treatment Systems, Reuse Strategies and User Perception-a Review. Water, Air, and Soil Pollution, 229:255 (8), p. 116.

Pidou, M., Avery, L., Stephenson, T., Jeffrey, P., Parsons, S. A., Liu, S., Memon, F. A. and Jefferson, B. (2008). Chemical solutions for greywater recycling. Chemosphere, 71(1), p. 147-155.

Pidou, M., Memon, F. A., Stephenson, T., Jefferson, B. and Jeffrey, P. (2007). Grey water recycling: treatment options and applications. In: Proceedings of Engineering Stability, Institute of Civil Engineers, 160 (3), p. 119131.

Siggins, A., Burton, V., Ross, C., Lowe, H. and Horswell, J. (2016). Effects of long-term greywater disposal on soil: A case study. Science of the Total Environment, 557-558, p. 627-635.

Stanton, K., Tibazarwa, C., Certa, H., Greggs, W., Hillebold, D., Jovanovich, L., Woltering, D. and Sedlak, R (2010) Environmental risk assessment of hydrotropes in the United States, Europe, and Australia. Integrated Environmental Assessment and Management, 6 (1), p. 155-163.

Yang, J. (2017). Hair Care Cosmetics, Chapter 36. In: Cosmetic Science and Technology, Theoretical Principles and Applications, p 601-615.

Winward, G. P., Avery, L. M., Stephenson, T. and Jefferson, B. (2008a) Chlorine disinfection of grey water for reuse: effect of organics and particles. Water Research, 42, 483-491.

Winward, G. P., Avery, L. M., Stephenson, T. and Jefferson, B. (2008b) Ultraviolet (UV) disinfection of grey water: particle size effects. Environmental Technology, 29(2), 235-244. 